\title{
Reverse Osmosis of Whey - Valuable Biocomponent of Feed and Food
}

\author{
MIRELA AHMADI ${ }^{1}$, IOAN PET ${ }^{2 *}$, LAVINIA STEF ${ }^{2}$, GABI DUMITRESCU ${ }^{2}$, MARIOARA NICULA ${ }^{2}$, \\ LAURA-IOSEFINA SMULEAC ${ }^{3}$, RAUL PASCALAU ${ }^{4}$, DOREL DRONCA ${ }^{2 *}$ \\ ${ }^{1}$ Banat's University of Agriculture Science and Veterinary Medicine "King Michael I of Romania" from Timisoara - \\ USAMVB, Faculty of Veterinary Medicine, 119 Calea Aradului, 300645, Timisoara, România \\ 2 Banat's University of Agriculture Science and Veterinary Medicine "King Michael I of Romania" from Timisoara - \\ USAMVB, Faculty of Bioengineering of Animal Production, 119 Calea Aradului, 300645, Timisoara, România \\ ${ }^{3}$ Banat's University of Agriculture Science and Veterinary Medicine "King Michael I of Romania" from Timisoara - \\ USAMVB, Faculty of Agriculture, 119 Calea Aradului, 300645, Timisoara, România \\ ${ }^{4}$ University of "Vasile Goldis" Arad, Department of Applied Modern Leanguages, 94 Revolutiei Str., Arad, AR-310025, \\ Romania
}

\begin{abstract}
Whey is a high-quality dairy by-product from cheese industry, being an important source of valuable proteins. It is important in human and animal nutrition due to its content in enzymes, hormones, vitamins, minerals, and antioxidant compounds, it has low lactose content, very little or it is free of lipids, but the dehydration (drying) technique must be very well chosen to preserve the quantity and quality of components. The objective of our study was to analyze the possibility of concentrating whey by reverse osmosis and having in view the possibility to preserve most of the biochemical properties of whey. Thus, we made comparative tests for quantitative determination of total protein, lipids, $\mathrm{pH}$ and acidity for - raw, skimmed and concentrated whey. The results showed that reverse osmosis is a good, cheap and easy-to-use method in cheese factories to obtain whey with wellpreserved components. Most of the farmers from western Romania (especially in Timis county) use whey as ingredient of feed products. Studies from previous years present whey as an ingredient of nutritional supplements for animal feeding plan, as well as an ingredient in supplements for athletes and alternative medicine. There are many technological options for whey processing, but the final option must be very well correlated with the final nutritional purpose.
\end{abstract}

Keywords: whey, feed, human, nutrition.

Whey is a natural product that is very rich in highly digestible proteins which are obtained from milk products technology as a by-product from cheese manufacturing and casein or yogurt production. It is a widely available product, where a few million tons are produced annually and are found in all milk processing units as a by-product. Whey is a very good source of highly digestible protein ( $\beta$-lactoglobulin, $\alpha$-lactalbumin, lactoferrin, immunoglobulin), and also carbohydrates (lactose, galactooligosaccharides).

Many researches provide information about the benefits of including whey in diet, that can prevent and/or attenuate different diseases, help the conventional therapies, and can augment the recovery after physical effort and medical problems [1-3].

Since long time ago, experimental studies proved that whey can be used in ruminants feeding plan (up to $30 \%$ from the dry-matter intake) and swine (up to $20 \%$ from the dry-matter intake). In ruminans adding dry or concentrated/condensed whey to corn silages or grass, improved the digestibility, the feed patability is improved, the concentration of ammonia nitrogen is reduced, while the feed urea is increased [4,5]. As well, in lactating cattle whey is used in gradual adaptation to the feeding plan to prevent diarrhea due to its lactose content, with very good performance in milk yield and milk calcium and magnesium content [6].

Depending on milk sources, whey represents about $80-90 \%$ of milk volume, and because it is a very low lipid product - contains about $50 \%$ of water soluble nutrients from original milk (soluble proteins, carbohydrates, water soluble vitamins and minerals). According to Matti Harju and Matti Heikonen the composition of common cheese whey is presented in Table 1 [7].

Whey is industrially obtained as a by-product from producing hard, semi-hard and soft cheese, and from producing casein.

*email: ioan.petz@yahoo.com; ddronca@animalsci-tm.ro 
Table 1

CHEESE WHEY COMPOSITION IN NUTRIENTS

\begin{tabular}{|c|c|c|}
\hline Specification & $\begin{array}{c}\text { Unit of } \\
\text { measurement) }\end{array}$ & Value \\
\hline Protein & $\%$ (by mass) & 0.7 \\
\hline Lactose & $\%$ & 4.5 \\
\hline Lipids & $\%$ & 0.1 \\
\hline Ash & $\%$ & 0.5 \\
\hline Dry content & $\mathrm{mg} / \mathrm{L}$ & 6.0 \\
\hline Calcium & $\mathrm{mg} / \mathrm{L}$ & 350 \\
\hline Magnesium & $\mathrm{mg} / \mathrm{L}$ & 90 \\
\hline Sodium & $\mathrm{mg} / \mathrm{L}$ & 450 \\
\hline Potassium & $\mathrm{mg} / \mathrm{L}$ & 1400 \\
\hline Phosphorus & $\mathrm{mg} / \mathrm{L}$ & 450 \\
\hline Chloride & $\mathrm{mg} / \mathrm{L}$ & 1000 \\
\hline Lactic acid & $\mathrm{mg} / \mathrm{L}$ & 900 \\
\hline Citric acid & & 1400 \\
\hline
\end{tabular}

According to data published by Slavov [8] the whey obtained in cheese technology is also called "sweet whey" and is characterized by a moderate acid $\mathrm{pH}(5.9-6.6)$, while the whey obtains after mineral-acid precipitated of casein has a more acidic $\mathrm{pH}$ (4.3-4.6). The whey composition is generally the same and does not depend on the technology in the major nutrients, but the minerals are higher in whey obtain in casein manufactured (Table 2) [9].

Whey processing alternatives offers various possibilities for obtaining different valuable products such as whey cream (separation process); powder whey or condensed whey (concentration of total solids); concentrated whey protein, lactoperoxidase, lactoferrin, $\alpha$-lactalbumin, $\beta$-lactoglobulin, lactose (fractionation of total solids); single cell protein, ethyl alcohol, lactic acid, cobalamin, galactose, glucose (lactose conversion); and lactosyl-urea and ammonium lactate (chemical reactions) [9].

Table 2

WHEY COMPOSITION PERCENTAGE OBTAIN IN CHEESE AND CASEIN PRODUCTION

\begin{tabular}{|c|c|c|}
\hline \multirow{2}{*}{$\begin{array}{c}\text { Components specification } \\
\text { in whey }\end{array}$} & \multicolumn{2}{|c|}{ Whey (\%) obtain in } \\
\cline { 2 - 3 } & Cheese manufactured process & $\begin{array}{c}\text { Mineral-acid (HCl) precipitation } \\
\text { casein process }\end{array}$ \\
\hline True protein & 0.60 & 0.60 \\
\hline Total lipids & 0.05 & 0.05 \\
\hline Carbohydrate - Lactose & 4.5 & 4.6 \\
\hline Non-protein nitrogen & 0.20 & 0.20 \\
\hline Total solids & 6.0 & 6.4 \\
\hline Water & 94 & 93.6 \\
\hline Lactic acid & 0.05 & 0.05 \\
\hline Ash (total minerals) & 0.5 & 0.8 \\
\hline Calcium & 0.035 & 0.12 \\
\hline Phosphorus & 0.040 & 0.065 \\
\hline Sodium & 0.045 & 0.050 \\
\hline Potassium & 0.14 & 0.16 \\
\hline
\end{tabular}

These products can be used as supplements or ingredients for animal feeding plan with increased results in animal growth and development and also in quality of animal products (milk, eggs, meat).

Whey proteins represent the majority of cow's milk whey (approximately $85 \%$ of cow milk whey) of $\beta$-lactoglobulin $(-35 \%), \alpha$-lactalbumin $(-12 \%)$, glycomacropeptide $(-12 \%)$, proteose peptone $3(-12 \%)$, immunoglobulins $(-8 \%)$, serum albumin $(-5 \%)$, lactoferrin $(-1 \%)$, lactoperoxidase $(-0.5 \%)$, and other different proteins - each in small amount $(-15 \%)$ [10].

From another perspective whey is considered a strong pollutant if it's discharged into the sewage system because it contains high concentration of organic compounds which lead to a high biochemical oxygen demand - consuming 30$40 \mathrm{~g}$ oxygen per one liter of whey during biodegradation [5].

Because the large cheese factories are processing very large amounts of milk with very high whey production, it's necessary to have in view both aspects: transformation of whey in useful products, and limitation of pollution.

\section{Experimental part}

Our research has been carried out in a private milk processing plant from Timis County - Romania, which also processes the cheese whey before the product is exported. The whey processing plan was necessary because in the 
summer time, whey quantity is high and producers needed to find a way to process and capitalize it. For a very good whey quality (especially whey protein), after different tests, the degreasing (maximum $0.1 \%$ fat) followed by reverse osmosis for concentration the whey, was the best applicable solution.

Total lipids, protein, $\mathrm{pH}$ we measured on raw sweet ovine whey (resulting after cheese production), skimmed whey (after whey degreasing by centrifugation), and concentrated skimmed whey (after reverse osmosis).

Whey acidity was evaluated using the Soxhlet-Henkel method [11], $\mathrm{pH}$ was determined using Eutech Instruments $\mathrm{pH} 700$, total fat was determined by Gerber method [12], protein concentration was evaluated using modified Steinegger method [13], dry matter and humidity was performed using oven-dry method, and reagents used for analytical determinations were Merck and Sigma-Aldrich. There were twenty-seven different whey samples were collected - as raw whey, skimmed whey and concentrated skimmed whey. The $\mathrm{pH}$, acidity, total lipids and total protein were performed on all samples, and finally we calculated the mean and standard deviation $( \pm \mathrm{SD})$. The results from the laboratory analysis, the used method, the presentation of the results, and final concentrated skimmed whey quality were accepted by both companies (the seller as an Romanian exporter and buyer as an foreign importer).

\section{Results and discussions}

The nutritional quality of whey is depending also on milk animal species. However, the most important nutritive characteristics are proteins and minerals, and less hydrosoluble vitamins, enzymes and lactose. Whey is frequently used as a source of easy digested, high-valuable proteins - especially when developing diets for farm animal and in the production of nutritional supplements for humans. For these technological reasons, and also for the good preservation until further processing, the whey has to have specific acidity, $\mathrm{pH}$, must have little to no lipid content, and has to have minimal protein and lactose concentration.

The analytical results for $\mathrm{pH}$ (pH-meter method) and acidity (titration method) for raw whey (RW), skimmed whey (SW), and concentrated skimmed whey (CSW) presented significant acidity differences between the raw whey and concentrated skimmed whey (figure 1).

The results presented graphycally showed that the $\mathrm{pH}$ decreases with $11.16 \%$ in concentrated skimmed whey compared (CSW) to raw whey (RW), while the acidity increased very significant in the final concentrated product compared to the primary whey (increased 4.t times). The total lipid concentration decreases in the skimmed whey when compared to raw whey due to the degreasing process (by centrifugation separation), and normally increased in the final concentrated skimmed whey compared to skimmed whey. The degreasing process is mandatory for reverse osmosis and for a better solubilization and emulsification of the concentrated whey. Total protein progressively increased from $1.79 \%$ in raw cheese whey to $2.06 \%$ in skimmed whey and to $7.38 \%$ in concentrated skimmed whey.

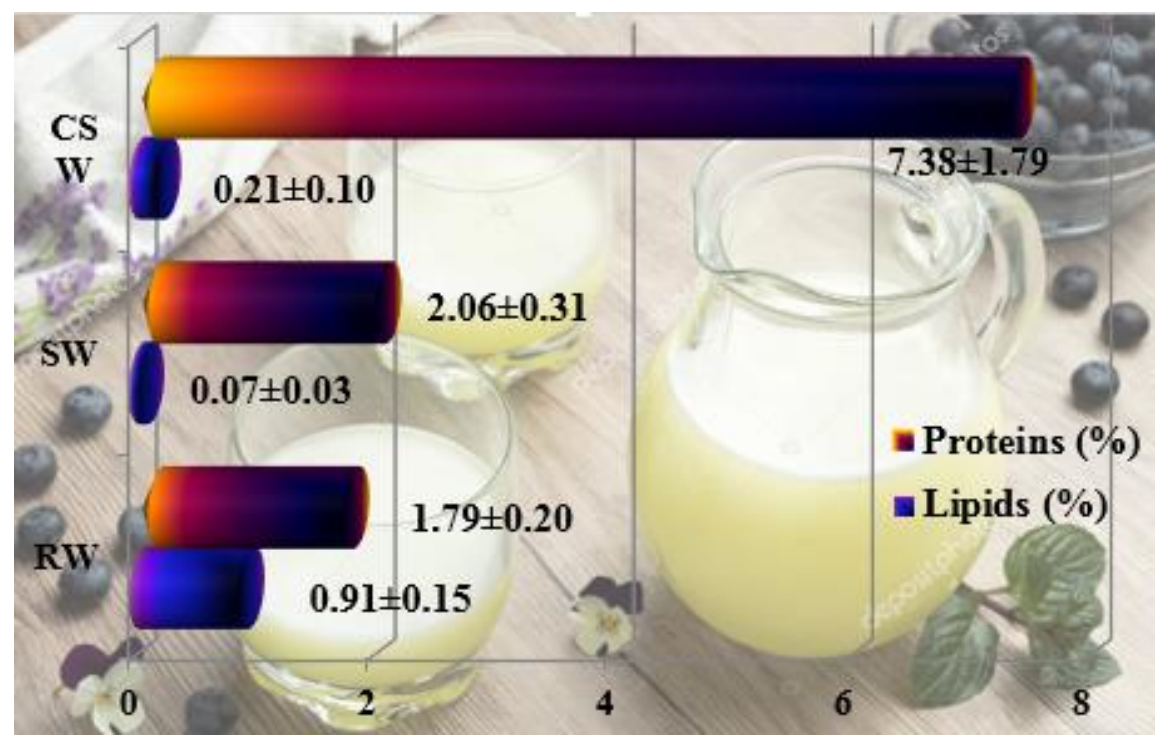

Fig. 1. Acidity and $\mathrm{pH}$ for raw whey, skimmed whey, and concentrated skimmed whey 


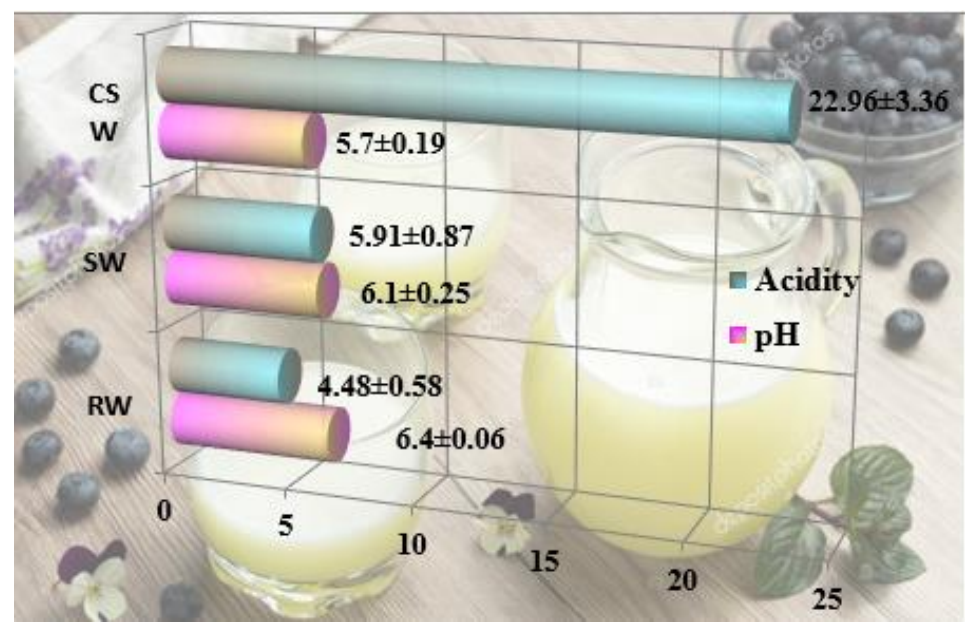

Fig. 2. Total proteins and lipids content in raw whey, skimmed whey, and concentrated skimmed whey

The analytical results for total lipids (\%) and total protein (\%) for raw whey (RW), skimmed whey (SW), and concentrated skimmed whey (CSW) presented significant total protein differences between the raw whey and concentrated skimmed whey (figure 2).

Dry matter and humidity was evaluated for final concentrated skimmed whey. Thus, the dry matter percent concentration in final product after reverse osmosis of whey was $21.73 \pm 0.63$ (mean \pm SD), and generally from 900 liters of raw whey was industrially obtained approximately 300 liters of concentrated skimmed whey - and this finally product is then exported and commercialized.

The method used to concentrate the cheese whey is very important in determining the final quality of the concentrated whey. There are many operations solutions (ultrafiltration, nanofiltration, reverse osmosis, polymerization) outling procedures to recover, purify, concentrate and reincorporate whey with special attention on protein and lactose components of whey [14-19].

Ultrafiltration enriched $\alpha$-Lactalbumin, $\beta$-Lactroprotein, and total protein concentration in the permeated whey compared to fresh whey, when hydrophobic $50 \mathrm{Kg} / \mathrm{mol}$ and hydrophilic $30 \mathrm{Kg} / \mathrm{mol}$ cut-off membrane was used. To analyse the concentration of whey proteins there are several methods that can be used, but UV $205 \mathrm{~nm}$ and Lowry methods are highly recommended, being the most accurate - having in view the presence of some interference compounds compared to the Bradford method [15].

Whey ultrafiltration using ceramic membrane technology followed by reverse osmosis using organic membrane system is a good technological option for protein and lactose re-use. The raw whey is pre-treated and heated, then is ultrafiltered which results in protein retentate and protein permeate. The membrane characteristics for ultrafiltration is very important for protein and lactose quantity and quality results. Additionally the acidity, pressure, temperature, and volume reduction factors from the raw whey are critical factors which determine quantity and quality for the protein and lactose. Raw whey protein concentration was $5 \mathrm{~g} / \mathrm{Kg}$, and after ultrafiltration the protein concentration was $12.34 \mathrm{~g} / \mathrm{Kg}$ in collected retentate [17].

Polymerization of fresh whey cheese is another good method to obtain polymerized whey proteins which are very stable to a heating temperature of $75^{\circ} \mathrm{C}$ for 10 minutes and does not negatively effect the probiotic properties. Polymerized whey proteins (PWP) can be obtain as liquid (LPWP) or concentrated CPWP). When PWP are used to yogurt preparation, do not lead to significant changes in $\mathrm{pH}$, totals solids, titrable acidity, protein content, texture, viscosity and syneresis, no matter if LPWP or CPWP is used [20]. Also, the spray-drying method was successfully used for growth and spray drying of some probiotics based on Lactobacillus casei BL23 and Propionibacterium freudenreichii ITG P20 using 30\% concentrated sweet whey. Spray-drying is a cost-efficient method for obtaining powder probiotics from sweet whey, and the multi-stage drying is more efficient then one-stage spray drying, improving the tolerance of Propionibacterium freudenreichii against stimulating the intestinal fluid [21-23]. Another study proves that whey it is a effective encapsulating agent for Bifidobacterium Bb-12 using the spray-drying method. Thus, the survival of Bifidobacterium Bb-12 encapsulated with whey in the gastrointestinal environment and also the tolerance to sodium chloride was excellent - which could be used in animal and human feeding plan [24]. Doherty's research team tested the efficiency of using the whey protein isolate as a matrix for the encapsulation of Lactobacillus rhamnosus GG. The L. rhamnosus is a good gastro-intestinal probiotic and the encapsulated micro-bead matrices based on whey protein isolates presented a homogenous distribution of live probiotics, characterized by peptic-resistance and acid-stability which are the most required probiotics properties [25]. 
Whey is a dairy product that could be a good source of calcium, especially when it is concentrated. Likewise, whey contains minerals and lactic acid which is a good source of calcium lactate crystals - chemicals that are responsible for the concentrated acid whey thickening [26]. Other minerals are very important for concentrated whey proteins or isolates, but some potential toxic minerals or essential minerals in excess could decrease the whey quality or could even make it improper as an ingredient of feed or food [27-31].

Usually after concentration of cheese whey, the product is fully dehydrated by lyophilization (freeze-dry) or encapsulation - because it is easier to preserve and to incorporate as an ingredient of other products [32, 33]. In this case, lyophilization is a good option because the proteins are protected and preserved (preventing protein coagulation and hydro-soluble vitamins alteration). Different researcher teams have proposed other novo-technologie s that could be used to obtain protein microcapsules enhanced with different antioxidants, vitamins, minerals, enzymes, and plant extracts for nutraceutical production [33,34]. The nutraceuticals have high biologic value that can lower the diet energetic value, used in humans' diet and supplemented animal rations.

Also, there are study that highlight the importance of using sweet and acid whey for enzymatic generation of lactulose. The initial concentration of lactose and fructose is very important for enzymatic method to obtain lactulose using $\beta$-galactosidases. Using whey in feed composition - it is very important to know exactely how much fructose and lactose have to be in whey to assure the best yeld for lactulose production [8].

\section{Conclusions}

Whey is a valuable natural proteins and lactose resource, being considered a waste product in dairy technology. Whey proteins are easily digestible, have good emulsification and solubilization properties. Reverse osmosis is a good technological approach to used for concentrating the cheese whey, but before osmosis concentration, the whey is mandatory to be degreased to a very low lipid concentration or even lipid free whey.

The raw whey presented $0.91 \%$ lipids and after degreasing occurred by centrifuging the skimmed whey composition presented $0.07 \%$ lipids, while the concentrated skimmed whey contained $0.21 \%$ lipids. Total concentrated skimmed whey protein $(7.38 \%)$ was significantly greater compared to skimmed whey $(2.06 \%)$ and to raw whey $(1.79 \%)$. Also the $\mathrm{pH}$ decreases in concentrated skimmed whey, the acidity increased significantly in the final product, and the dry matter from concentrated skimmed whey was $21.73 \%$. Whey could become a valuable nutritional product and concentration of whey by reverse osmosis could be a good method of recovering the by-product from the cheese plants for a good purpose and thus, whey would not be classified as an environmental pollutant.

\section{References}

1.KRISSANSEN, G.W., J. Am. Coll. Nutr., 26, no. 6, 2017, p. 713S.

2.TUdoran, M., TUdORAN, C., CIOCARLIE, T., POP, G. N., BERCEANU-VADUVA, M. M., VELIMIROVICI, D. E., AHMED, A. A., BERCEANU-VADUVA, D. M., Mat. Plast., 56, no.1, 2019, p.37-40

3.VADUVA, D. M. B., VELIMIROVICI, D. E., (VADUVA, M. M. B., STANGA, L., PETRESCU, H., RADA, M., CIPU, D., VADUVA, B.M.

B.,RADULESCU, M., Mat. Plast., 55, no.3, 2018, p.372-375

4.SCHINGOETHE, D.J., Journal of Diary Science, 59, no. 3, 1976, p. 556.

5.EL-TANBOLY, E.S., EL-HOFI, M.K., J. Nutr. Health Food Eng., 6, no. 5, 2017, 00215

6.EL-SHEWY, A.A., Science International, 4, no. 3, 2016, p. 80.

7.MATTI, H., MATTI, H., 1989, Patent US4855056A

8.SCHMIDT, C.M., BALINGER, F., CONRAD, J., GÜNTER, J., BEIFUSS, U., SLAVOV, A.K., Food Technol. Biotechnol., 55, no. 1, 2017, p. 14.

9.***Tetra Pak International SA, Chapter 15: Whey Processing, in Dairy Processing Handbook. http://dairyprocessinghandbook.com/ chapter/whey-processing. Accessed 15.07.2018

10.BARRINGTON, R., 2013, http://www.robertbarrington.net/the-composition-of-whey-protein

11.*** Manuals of food quality control, 8. Food analysis: quality, adulteration and tests of identity, FAO Food and Nutrition Paper 14/8, Food and Agriculture Organization of the United Nations, Reprinted 1997

12.***AOAC Official Method 2000.18, Fat content - Gerber Method by Weight (Method I), 2002 AOAC International

13.MOORE, J.C., DEVRIES, J.W., LIPP, M., GRIFFTHS, J.C., ABERNETHY, D.R., Wiley Online Library - Comprehensive Reviews in Food Sciences and Food Safety, 9, no. 4, 2010, p. 330.

14.YORGUN, M.S., AKMEHMET BALCIOGLU, I., SAYGIN, O., Desalination, 229, no. 1-3, 2008 , p. 204.

15.METSÄMUURONEN, S., MÄNTTÄRI, M., NYSTRÖM, M., Desalination, 283, no. 12, p.156.

16.SCHUCK, P., DOLIVET, A., JEANTET, R., Analytical Methods for Food and Dairy Powders, Wiley-Blackwell, Oxford, 2012.

17.BELHAMIDI, S., LARIF, M., ACHATEI, A., HABZIZ, S., ZOUHRI, N., RAFIQ, M., CHOUNI, S., ELHANNOUNI, F., ELMIDAOUI. A.,

J. Mater. Environ. Sci., 6, no. 3, 2015, p. 861.

18.WENTEN, I.G., KHOIRUDDIN, A., Desalination, 391, 2016, p. 112.

19.WEN-QIONG, W., LAN-WEI, Z., XUE, H., YI, L., Food Chemistry, 215, 2017, p. 31.

20.FANG, T., GUO, M., Journal of Dairy Science, 102, no. 9, p.7884.

21.HUANG, S., CAUTY, C., DOLIVET, A., LE LOIR, Y., CHEN, X.D., SCHUCK, P., JAN, G., JEANTET, R., Journal of Fuctional Foods, 23, no. 5, 2016a, p. 453 .

22.HUANG, S., RABAH, H., JARDIN, J., BRIARD-BION, V., PARAYER, S., MAILLARD, M.B., LOIR, Y.L., CHEN, X.D., SCHUCK, P., JEANTET, R., JAN, G., Applied Environmental Microbiology, 82, no.8, 2016 b, p. 4641. 
23.HUANG, S., MÉJEAN, S., RABAH, H., DOLIVET, A., LE LOIR, Y., CHEN, X.D., JAN., G., JEANTET, R., SCHICK, P., Journal of Food Engineering, 196, 2017, p.11.

24.DE CASTRO-CISLAGHI, F.P., SILVA, C.D.R., FRITZEN-FREIRE, C.B., LORENZ, J.G., SANT'ANNA, E.S., Journal of Food Engineering, 113, no. 2, 2012, p. 186.

25.DOHERTY, S.B., GEE, V.L., ROSS, R.P., STANTON, C., FITZGERALD, G.F., BRODKORB, A., Food Hydrocolloids, 25, no. 6, 2011, p.1604.

26.MIMOUNI, A., BOUHALlAB, S., FAMELART, M.H., NAEGELE, D., SCHUCK, P., Journal of Dairy Science, 90, no. 1, 2007 , p.57.

27.VERMESAN, H., PUP, M., AHMADI, M., VERMEŞAN, D., PREJBEANU, R., Rev. Chim. (Bucharest), 59, no. 8, 2008 , p. 891.

28.PREJBEANU, R., AHMADI, M., SCURTU, M., VERMEŞAN, D., OLARIU, L., Rev. Chim. (Bucharest), 62, no. 7, 2011 , p. 750.

29.DELEANU, B., SCURTU, M., AHMADI, M., TULCAN, C., PREJBEANU, R., DRONCA, D., Rev. Chim. (Bucharest), 66, no. 9, 2015, p. 1306.

30.NICUlA, M., PACAlA, N., STEF, L., PET, I., IANCU, T., DRONCA, D., AHMADI, M., GHERBON, A., DELEANU, B., Rev. Chim. (Bucharest), 68, no. 8, 2017, p. 1807.

31.NICULA, M., PACALA, N., STEF, L., PET, I., DRONCA, D., GHERBON, A., AHMADI, M., Rev. Chim. (Bucharest), 68, no. 12, 2017, p. 2747.

32.PALATNIK, D.R., OSTERMANN-PORCEL, M.V., GONZALES, U., ZARITZKY, N., CAMPDERROS, M.E., LWT - Food Science and Technology, 63, no. 1, 2015, p. 331.

33.PARTHASARATHI, S., ANANDHARAMAKRISHNAN, A., Food and Bioproducts Processing, 100(A), 2016, p. 469.

34.LOPEZ-RUBIO, A., LAGARON, J.M., Innovative Food Science and Emerging Technologies, 13, 2012, p. 200.

Manuscript received: 30.09 .2019 
